\title{
CONTEMPORARy Challenges FOR EDUCATION IN Conflict Affected Countries
}

\author{
Alan Smith \\ University of Ulster
}

\begin{abstract}
The importance of education to human development is emphasised by its central place in achieving the Millennium Development Goals (MDGs) and reflected in the global initiative Education for All (EFA) aimed at securing primary education for all children by the year 2015. There are many impediments to the achievement of universal primary education. These include lack of priority to education on the part of national governments such as, insufficient spending as a percentage of GNP or inequitable distribution of funding and resources. Significant barriers to education, particularly within low income countries, include poverty, child labour, distance from school, unequal access due to gender or cultural factors and the existence of conflict. Although the number of out-of-school primary-age children in the world has fallen in recent years, there has been little improvement in conflict affected countries. These countries are home to half of all children out of school (currently 28.5 million out of 57 million children), yet they receive less than one-fifth of education aid. This paper draws on research for the 2011 EFA Global Monitoring Report to highlight a number of significant challenges for education in these countries and the contribution that education might make to longer term peacebuilding.
\end{abstract}

KEYWORDS: Education for All, Conflict, Peacebuilding

\section{Introduction}

In terms of the number of armed conflicts the world is becoming less violent (Global Monitoring Report, 2011, p.136). However, the nature of conflict is changing, with important consequences for populations and their education. Conflicts are now overwhelmingly fought within rather than between states and many involve protracted violence. Civilians, schools and teachers are increasingly targets of attack as international norms on warfare are disregarded. Findings from the Global Monitoring Report indicate that twenty-eight million children are out of school in conflictaffected countries, half of the world total. Children in conflict affected countries are twice as likely as children in other low income countries to die before their fifth birthday. Refugees and internally displaced people face major barriers to education, and conflict-affected countries have some of the largest gender inequalities and lowest literacy levels in the world. Yet education remains a low priority in situations of conflict - it receives just $2 \%$ of humanitarian aid and only $38 \%$ of emergency aid requests for education are met. Whilst development assistance to basic education has doubled since 2002 to US\$4.7 billion, current aid levels fall far short of the US\$16 billion required annually to close the external financing gap in low-income countries. Yet, twenty-one of the world's poorest developing countries continue to spend more on military budgets than primary education, when redirecting just $10 \%$ into education could put almost 10 million additional children into school. The military spending of donor governments is US\$1029 billion per year, yet 6 days of this would meet the funding needed to achieve Education for All.

\section{Education as a Humanitarian Response}

Since the Machel Report (1995), and a further review in 2009, there has been increased awareness of the impact of conflict on education systems and the importance of education for children and youth as part of post conflict reconstruction. Child protection and child rights advocates

\footnotetext{
Correspondence can be directed to: a.smith@ulster.ac.uk
} 
have placed issues related to children and conflict on the international agenda and argued for the education of refugees and displaced persons, strategies to prevent the use of child soldiers, protection for girls against sex crimes, and the provision of landmine education and trauma counselling. The growing field of 'education in emergencies' has made arguments that education should be given more priority in emergency responses (Brock \& McCorriston, 2008; INEE, 2010) and suggest that education can provide a physically safe space for learning and psychosocial development, interaction with peers and trusted adults, and opportunities to receive food and medical attention. Other arguments are that education can mitigate the psychosocial impact of conflict by creating stability, structure, and hope for the future. Furthermore, critical information and problem-solving skills may protect children and youth from exploitation and harm, abduction, child soldiering, and sexual and gender-based violence. HIV/AIDS prevention, landmine safety and peacebuilding education can also provide lifesaving information. It is also argued that education that promotes the rights and responsibilities of children, especially through active citizenship, can provide long-term benefits for society.

Despite these arguments the Education for All, Global Monitoring Report (2011) highlights reports that children and schools are increasingly on the front line of armed conflicts, with classrooms, teachers and pupils seen as legitimate targets (O'Malley, 2010). Children are often forcibly recruited as soldiers and the UN Secretary General's report to the Security Council, covering fifteen countries, identifies fifty-seven groups recruiting child soldiers (United Nations, 2010). Rape and sexual violence are still used as weapons of war and the psychological trauma for those affected inevitably impairs learning whilst the threat of such violence further impairs mobility and stops children from attending school. Mass displacement continues to be a significant consequence of violence and UN data suggests that almost half of the 43 million people displaced globally are under 18. Whilst efforts have been made to provide education as part of a humanitarian response, UN data continues to paint a disturbing picture of the state of education in refugee camps. Enrolment rates averaged $69 \%$ for primary school and just $30 \%$ for secondary school. Pupil/teacher ratios were very high, nearly one-third of camps reported ratios of 50:1 or more and many teachers were untrained (Global Monitoring Report, 2011).

\section{Conflict Sensitive Education}

Education is also a means by which social and cultural values are transmitted from generation to generation and depending on the values concerned, these may convey negative stereotypes or encourage attitudes that explicitly or implicitly condone violence or generate conflict. Research by Bush and Salterelli (2000) documented how education may become 'part of the problem', for example, through segregated education that maintains inequality between groups, unequal access to education or the manipulation of history and textbooks. A number of studies have highlighted aspects of education that have implications for conflict by fuelling grievances, stereotypes, xenophobia and other antagonisms (Smith \& Vaux, 2003; Buckland, 2005; Tawil \& Harley, 2004). This has led to the development of the concept of 'conflict sensitive education', that is, the provision of education in a way that is sensitive to the dynamics of conflict in the context in which it operates and in a way that does not exacerbate conflict (does no harm).

The research literature on linkages between education and conflict has increased significantly in the past decade. Most of this literature involves qualitative research and case studies and so it is not possible to be definitive about causal relationships or the direction of causality (for example, whether certain forms of education provision fuel conflict, or are a consequence of conflict). However, the prevalence of similar concerns (for example, about the control, form and content of education) across many different social and cultural contexts suggests that there is good reason to pay attention to the role of education in conflict-affected situations. There are a number of key areas that require careful attention to policy and practices so that education is conflict sensitive. 


\section{The Role of Education in State Building and Citizenship Education}

It is important to distinguish between 'state building' and 'nation building'. The two are often conflated yet can represent very different ideologies. Concepts of nation building often refer to the development of a state where citizens share the same social, cultural, religious background. Indeed, concepts of the nation often transcend state boundaries and include diaspora that can have significant influence on state development, so identity is a central concept in nation building. However, increasing globalization, trade and movement of people means that the concept of the homogeneous nation state is being challenged, partly through the emergence of regional and supra national entities such as the European Union, and partly due to the increasing diversity of citizens within states. This means that it is no longer tenable to define citizenship solely in terms of ethnic, religious or cultural identity. The concept of state building places more emphasis on equal rights and responsibilities of all citizens irrespective of their ethnic, religious or cultural identity. Education and schooling therefore becomes a key instrument in terms of which of these ideologies is taught (identity-based, nationality or rights-based, citizenship) and which is most dominant.

In many societies civic or citizenship education is an explicit and formal part of the school curriculum. Gulalp (2006) provides case studies from Europe and the Middle East that address the question of citizenship and ethnic conflict from the foundation of the nation state, to the current challenges raised by globalization. An examination of six countries (Germany, Greece, Iraq, Israel, Lebanon and Turkey) suggests that ethnic or religious identity lies at the core of the national community, ultimately determining the state's definition and treatment of its citizens. Forms of citizenship education may range from traditional civics programmes that often take a country's constitution or independence as the starting point to then explain the institutions of government and how they operate. More recently there is also a trend towards enquiry based curricula that investigate what it means to be a citizen and this approach may be more appropriate in pluralist and conflict-affected societies since it frames citizenship in terms of common rights and responsibilities rather than identity factors such as ethnicity, religion or culture. Pedagogies also vary from didactic approaches, often through learning facts from a textbook to more active learning through community-based projects. Even where there is no explicit civics or citizenship programme, other parts of the curriculum such as history and social studies may carry strong messages about the nature of the state. Such messages socialise children about who may be regarded as a citizen, attitudes to various groups and regions within the country and those who come from elsewhere. In addition, the informal curriculum may also carry strong messages about the relationship between peoples within the state and the relationship between the state and its citizens. For example, in many countries education is one of the main ways that citizens are encouraged to develop loyalty to the state through the daily routine of singing the national anthem, raising the national flag, display of leaders' portraits or celebration of national days. Such practices may contribute to a sense of national unity, but can also be particularly problematic in conflict-affected countries, especially where the legitimacy of the state is being challenged. Irrespective of whether citizenship education is explicit or implicit, school curricula also carry messages about the state and militarism, for example, whether conscription exists or if citizens are expected to undertake military service or some other form of national service. A study of citizenship education in Israel and the USA by Ben-Porath (2006) suggests that, at times of war patriotic forms of citizenship dominate in order to secure national unity, whilst democracy and critical debate in the public discourse are constrained. Another study by Ichilov (2004), however, suggests that more liberal teachers have the greatest impact on the political socialization of Israeli and Palestinian youth through citizenship education.

The centrality of citizenship education to the formation of national identity means that it is particularly important to consider how citizenship education is functioning in conflict affected and post-conflict countries and whether it contributes to peacebuilding. In Rwanda, for example, an attempt is being made to remove ethnicity from the concept of citizenship, 
'Conflict and reconciliation in Rwanda are closely tied to the public discourse on citizenship. After independence, the notion of citizenship was employed to divide the polis by reducing citizenship to ethnic Hutu identity, entailing the exclusion of all Tutsi, while today, after the genocide, citizenship is based on 'Rwandanness' and all ethnic references are eradicated in the public discourse.' (Buckley-zistel, 2006, p.101)

Whilst, in post-conflict Northern Ireland where children grow up in communities that define themselves as either British or Irish, the citizenship curriculum focuses less on the concept of one common nationality and more on questions about diversity, equality and human rights within a divided society emerging from violent conflict (Smith, 2003). A recent evaluation indicated that pupils developed more positive attitudes towards inter-group relations, accompanied by a decline in trust in political institutions.

\section{Governance of the Education System}

Aragon and Vegas (2009) highlight two distinctive aspects to definitions of governance. The first concerns who has political control of a system and the context this creates, 'governance is defined mainly in terms of the process of policy-making (e.g. how the rules of a political regime provide the context in which policy-making is carried out)'. The second aspect refers more to technical capacity and the ability to implement policies. It is the former of these that is most likely to be contentious, particularly in conflict-affected countries since it can give rise to charges of bias and discrimination, although lack of technical expertise and capacity can also lead to grievances over inequalities due to poor implementation and policy outcomes. In addition, government preoccupation with security responses to terrorist threats may lead to increased, unchecked authoritarianism, particularly where 'special powers' are introduced that limit the right to freedom of expression or the suspension of normal legal processes (Carrión, 2006). In such situations governments may feel even more need to control state institutions such as the education system and educators may feel constrained to engage in critical enquiry of state policies and actions.

The existence of conflict inevitably raises questions concerning the views of government and non-state armed groups on the purpose of education and the extent to which education is seen as a tool for political or ideological purposes. Involvement in operational matters, such as education appointments, deployment of teachers, determination of the curriculum etc., may provide some indication of the extent to which education is being used for highly political purposes. In many circumstances political elites are likely to want to use education to benefit their supporters and strengthen their own power base. Where there is conflict this suggests an even greater need for systems and structures that protect the education sector from political bias, potential corruption and interference in operational decisions. At all levels of the education system governance is a crucial issue. The arrangements that are in place for representation and participation in consultation, decision-making and governance may be potential sources of conflict, or they may be opportunities for inclusion and the resolution of grievances. Arrangements for transparency and accountability also reflect the system's capacity to accept and address inequalities that can otherwise become sources of conflict.

Decentralisation of education systems has generally been regarded as a means of bringing about more accountability and ownership of schooling. In the case of conflict-affected countries the situation may be more complex and context dependent. For example, in analysing post-conflict reconstruction of education in Central America, Marques \& Bannon (2003) state, 'One has only to look at the conditions in which education services were (or were not) being delivered during the period of hostilities to see the importance of decentralizing functions, authority, funding, management and decision-making capacity to schools.' They cite the EDUCO programme that built on Escuelas Populares in El Salvador and the National Program of Community-Managed Schools for the Advancement of Education (PRONADE) in Guatemala as positive examples of post-conflict 
decentralisation in education. However, decentralisation may not always be so positive in other contexts, particularly during internal conflicts where government may have concerns about losing control of schooling to secessionist movements, for example, in regions of Columbia, Indonesia, Nepal or Sri Lanka. Even where decentralisation is introduced as part of post-conflict peace agreements, as for example in Bosnia and Herzegovina, fragmentation may strengthen control of the education system by local political interests and reinforce ethnic divisions if it is not moderated by strong institutions at the national level. The Dayton Peace Agreement (1995) introduced boundaries that became the basis for decentralization of political control in subsequent years. Responsibility for education in $\mathrm{BiH}$ is devolved to two entities ( $\mathrm{BiH}$ which has 10 Cantons and the Republika Srpska) and the District of Brčko. State government therefore has a limited role in education policies. The Ministry of Civil Affairs of BiH does not have substantive responsibilities in education, nor authority vis-à-vis the cantons, so there is no strong central authority. This means that the education system is highly fragmented with 14 ministries of education. The impact on education was not considered at the time, but the UN Special Rapporteur on the Right to Education identified 'two main issues which affect the enjoyment of the right to education in Bosnia and Herzegovina: the excessive fragmentation and politicization of the education system; and segregation between ethnic groups and assimilation processes based on ethnic motives.' (United Nations, 2007, p. 54).

Conflict-sensitive governance of education systems may therefore require fine judgements to be made about the balance between central control and devolution of authority to regional interests. Politicisation at the central level may be mitigated through protective mechanisms such as differentiation between functions such as policy-setting, policy advice, support to schools and service delivery. For example, a central Ministry might retain overall responsibility for setting policy, but create specialised agencies with responsibilities for planning, teacher education, curriculum and examinations etc. with governance arrangements that make them less susceptible to political interference. At the local level the arrangements that are in place for representation and participation in consultation, decision making and school governance may provide opportunities for inclusion of diverse interest groups that are more conflict sensitive.

\section{Segregated or Separate Schools}

A recurring theme in conflict-affected countries is the relationship between conflict and separate schooling based on identity factors such as language, ethnicity or religion. Identity factors are important for understanding conflict, partly because they may be mobilised to generate or escalate conflict, rather than being fundamental causes. Stewart (2000) refers to differences between identity-based groups as 'horizontal inequalities' to distinguish them from 'vertical inequalities' based on economic status and access to power, although these often map closely on each other and the potential for conflict may be greater. This means that it is difficult for education to be perceived as 'neutral' in conflict-affected countries, particularly where institutions such as schools are organised around identity factors. The evidence on the impact of separate schooling is contested and highly context-dependent. Gallagher (2010) provides some comparative examples of shared and separate schooling in divided societies and states that 'many mass education systems had assimilation as an overt aim'. He suggests that 'The distinction between segregated systems, in which minorities are obliged to use their own schools (such as apartheid South Africa, or the southern states of the U.S. prior to 1954), and separate systems, in which minorities run their own schools as a matter of choice, is important', but goes on to say that 'whether schooling systems are segregated or separate, there is evidence that such systems can have a detrimental impact on social cohesion', citing the detrimental impact on Arab-Israelis of the decision in the 1950s to formally divide schools in Israel. Drawing on the cases of Brazil, Britain, Canada, Israel, Malaysia, Netherlands, and the USA he concludes that the influence of schooling arrangements may be better understood as a combination of 'the structure of schools, the content of the curriculum, and the routes and opportunities available to young people'. This is consistent with the view that the impact of separate 
schooling needs to be considered in context and depends on whether such schools are perceived to be reinforcing assimilation, separate or shared development. Where mixing or integration takes place consideration needs also to be given to the nature of teaching and learning in the sense of whether identity factors are avoided or addressed explicitly.

Although few would argue that separate schooling is a fundamental cause of conflict, the prevalence of separate schooling based on identity factors in conflict-affected countries such as Bosnia and Herzegovina, Guatemala, Lebanon, Mozambique, Northern Ireland, Rwanda and Sri Lanka suggests that the linkage is not just a coincidence. One possible reason for the prevalence of separate schooling in conflict-affected countries is that the institutional structures reflect and replicate the political, social and cultural divisions within broader society. In Bosnia and Herzegovina, for example, many commentators point to the greater integration that existed within schools before the war. The impact of ethnic cleansing and displacements of populations has meant that parents are wary of the security of their children returning to their former schools. This is reflected in research by the Organisation for Security and Cooperation in Europe (OSCE) that highlights how parents will avoid their nearest school and travel some distance to enrol their child in another school associated with their own 'national identity'. In other situations children from different national backgrounds might attend the same school, but often at different times and being taught different curricula. Children have separate breaks, teachers have separate rooms and there may be little cooperation between separate administrations. UNICEF (2008) found that parents with children at 'two schools under one roof' were the most concerned for their safety. The situation in Brčko is more encouraging in that it has been possible for children to attend integrated schools. However, in many other conflict-affected countries there are examples of programmes that promote integration, often initiated by parents overcoming community divisions. The rationale for such programmes is that, whilst education may not have caused conflict, it can make a positive contribution towards peacebuilding by educating children together.

\section{Faith Based Schooling}

There are many historical reasons for close links between religion and schooling, not least because many churches provided schooling long before states were sufficiently organized to undertake this function. Grace (2003) suggests that, 'Much of the political and public debate about faith-based schooling is conducted at the level of generalised assertion and counter assertion' and that conclusions about the existence of faith-based schooling in conflict-affect societies such as Northern Ireland 'represent an ahistorical, decontextualised and oversimplified view of the causes of such conflict'. He refers to the example of 'about 120,000 Catholic schools serving almost 50 million students in a wide range of socioeconomic, political and cultural settings worldwide' and then cites a review of empirical research by Greeley (1998) to support arguments that children who attend faith-based schools in the USA are more tolerant than those who attend public schools. Short (2002) also challenges the notion that secular schools are better placed to promote tolerance in the UK. On the other hand, others such as Lawton (2005) argue that 'the benefits to the individual from a religious point of view are off-set against any potential impact on social cohesion.'

The United Nations Special Rapporteur recommends mixed-religion and mixed-race schools as the best way of combating intolerance and discrimination and suggests that faith-based schools 'can provide a prime and fertile terrain for lasting progress with respect to tolerance and non discrimination in connection with religion and belief' (UNHCR, 1995). A particular concern is that children should be protected from proselytisation according to Article 1 of the 'Declaration on the Elimination of all forms of Intolerance and of Discrimination based on Religion or Belief' (freedom of thought, conscience and religion and freedom to manifest one's religion or belief). From a rights-based perspective this may reflect a tension between parents 'prior right to choose the kind of education that shall be given to their children' (Universal Declaration of Human Rights, 1948), originally to protect against indoctrination by the state, and the child's right to education in 
'preparation for responsible life in a free society in the spirit of understanding, peace, tolerance, equality of sexes, and friendship among all peoples, ethnic, national and religious groups and persons of indigenous origin.' (UN Convention on the Rights of the Child 1989, Art 29). Concerns about proselysation and indoctrination have taken on added significance since the attacks of 9/11 with considerable attention being focused on the role of madrassas in central and south Asia. However, there is little consensus about the evidence on links between madrassas and recruitment to international terrorism. According to Grare (2007) the growth of madrassas in Pakistan was partly due to the state's failure to provide basic educational facilities since madrassas do not charge fees, but 'they became the main breeding grounds for sectarianism.' The International Crisis Group (ICG) claims that, 'Jihadi extremism is still propagated at radical madrassas in Pakistan', but there is fierce debate about the number of children who actually attend madrassas and the extent to which any of these religious schools are linked to terrorist activities' (Hasan, 2005). A study by Billquist \& Colbert (2006) found 'little evidence to connect madrassas to transnational terrorism', but they 'do have ties to domestic and regional violence, particularly Sunni-Shia sectarian violence in Pakistan'.

It is clear then that the evidence about the relationship between conflict and faith-based schooling is disputed, heavily context-dependent, and where there are concerns about faith based schooling in conflict-affected countries there is no conclusive evidence about causality, that is, whether the existence of separate faith-based schools fuels divisions or whether the demand for separate faith-based schools is a consequence of lack of confidence in government, lack of trust between groups within society or fear of assimilation. Overall, arguments for faith-based schooling tend to emphasize the right of parents to choose the type of school their child attends based on freedom of conscience and belief; a close inter-relationship between church, school and home; the potential for faith-based schools to promote values of tolerance and respect for difference and, in some cases, arguments that faith-based education relieves the state from some of the burden for school provision. Arguments against faith-based schools tend to emphasize that they may reinforce economic and ethnic divisions and that faith development should be the responsibility of the churches not the state. Despite lack of consensus, the prevalence of debate about faith-based schooling in conflict affected countries suggests that this is a policy area that requires careful consideration. From a conflict perspective, in any context, it is important to address two key questions about the role of faith-based schools within an education system. Firstly, what is the relationship between the state and faith-based schools? More specifically, is this relationship likely to be used as a justification for conflict. Policy-related questions include whether the position of the state should be secular, or accepting of faith-based schools. If faith-based schools exist should they be funded independently, partially funded or fully-funded by the state?

Secondly, what is the relationship between faith and teaching in schools? For example, if religious education is part of the school curriculum (even in schools that are not faith-based), is this comprised of religious instruction in a particular faith or a broader education about different religious faiths? What provisions are made for children of other faiths or none? Does the inclusion of religious education in the curriculum affect fair employment and who may be recruited as a teacher in faith-based schools? Arrangements for faith-based schools are likely to reflect power relations that exist within any given society, so for example, it may be that the dominant faith in a country will receive funding for its schools, but minority faiths are not permitted to establish their own schools, or do not receive state funding. In broad terms faith-based schools may institutionalize separate development in conflict affected countries, but they can also play a role in promoting values and practices that respect difference.

\section{Language of Instruction}

A UNESCO Position Paper on 'Education in a Multilingual World' identifies language as 'an essential element of inter-cultural education to encourage understanding between different groups and respect for fundamental rights.' (UNESCO, 2003). It supports mother tongue as a means of 
improving education quality, but also advocates 'bilingual and/or multilingual education as a means of promoting social and gender equality and a key element of linguistically diverse societies'. Many ethno-linguistic minority groups face a language barrier in education. Almost 70\% out-of-school girls belong to the ethnic, religious, linguistic, racial and other minorities (Lockheed \& Lewis, 2007). A World Bank report states that ' 50 percent of the world's out-of school children live in communities where the language of schooling is rarely, if ever, used at home' (World Bank, 2005). Rationales often used for monolingual and elitist language policies include: economic factors (multilingualism is costly), national unity (many languages fragment the population), power (to maintain central control). Some myths are that several media of instruction confuses students; use of mother tongue delays learning of national, official or international languages; and parents want a national or international language only. However, research indicates that mother tongue language of instruction results in (i) increased access and equity, (ii) improved learning outcomes, (iii) reduced repetition and dropout rates, (iv) socio-cultural benefits and (v) lower overall costs (Bender et al., 2005).

From a conflict perspective, the significant issue is that there are examples where language policies have been used in ways that exacerbate conflict. These include repression of mother tongue languages was as part of political conflict in Spain (Shabad \& Gunther, 1982); how overt bilingual and covert monolingual language policies fuel tensions with Uyghur nationalists in Xinjiang, China (Dwyer, 2005); how language policies in India, Pakistan and Sri Lanka were used as a means of dominating access to education by particular groups (Rösel, 2009); and difficulties even where there are attempts to use bilingual education as 'an approach to conflict resolution and the improvement of intergroup relations in Israel' (Amara et al., 2009). These issues are extremely complex in practice. The challenge from a conflict perspective is to develop language policies for education that contribute towards peacebuilding rather than exacerbate conflict. The Southeast Asian Ministers of Education organisation (SEAMEO) has links to policies, case studies and good practices in mother tongue as the language of instruction in Brunei Darussalam, Cambodia, Indonesia, Lao, Malaysia, Philippines, Singapore, Thailand and Vietnam (Kosonen \& Young 2009). Promotion of mother tongue as the medium of instruction can be the bridge to learning national, official and international languages. Multilingual policies may provide protection against conflict resulting from the exclusion of minorities from education or the use of language to reinforce unequal power relations between groups.

\section{The Role of Curriculum and Textbooks}

Every area of the curriculum carries values with the potential to communicate implicit and explicit, political messages. Language, literature, history, geography and the place of culture and religion are just some of the areas that often get drawn into controversy. Such areas are sometimes referred to as 'national subjects', in many instances tightly controlled by governments and regarded as essential tools for nation building. The teaching of history is an important concern in relation to conflict. Issues include epistemological issues about the impact on conflict of single narrative histories versus multiple perspectives approaches. This is also bound up in issues of whether education systems are driven by content and syllabuses or by skills and learning outcomes. In contested societies, arguments over textbook content can also become political and ideological battlegrounds. For example, there is a critique that education reconstruction in Afghanistan did not address attitudes of intolerance in school textbooks that have been reprinted using international development assistance (Spink, 2005). Part of the education reforms in Bosnia has involved the removal of 'offensive material' from history textbooks and such a process raises sensitive issues about the judgment of what is considered offensive and by whom, about who should be involved in such a process, and how it is implemented. Textbook review processes have a long history. For example, there were joint initiatives on French-German textbooks during the 1920s; German-Polish cooperation following the Second World War; a US-Soviet textbook project in the 1970s; more recently China and Korea have raised concerns about the treatment of WWII in Japanese textbooks (Höpken, 2003). The operation of a single textbook policy may offer a Ministry of Education a way of 
guaranteeing a minimum entitlement for all pupils to basic learning resources, particularly important in low-income countries and where equal access needs to be demonstrated. However, questions may also arise about who controls or benefits from the production of textbooks and about their content. The production of single textbooks for different linguistic communities also can present difficulties. For example, textbooks produced by Sinhalese authors in Sri Lanka were translated to produce copies for Tamil pupils. However, the Tamil Teachers' Union identified inaccuracies in the translated versions and claimed cultural bias in some of the illustrations and content matter. This led to demands for greater involvement of Tamil authors in textbook production (Wickrema \& Colenso, 2003). Attention to many of these areas may go some way towards ensuring that the content of education provision does not exacerbate conflict, but there are also arguments that education should not merely do no harm, but contribute to building peace within conflict affected societies.

\section{Education and Peacebuilding}

In 2006 the UN secretary General established a new UN Peace Building Commission (PBC), the Peacebuilding Support Office (PBSO) and the Peacebuilding Fund (PBF). From 2006 until February 2009 the PBF received pledges from 45 donors amounting to $\$ 319.3$ million and is currently supporting more than 100 projects in 15 countries. This raises a number of questions about the way that education might engage more strongly with UN peacebuilding. In situations where peace processes are underway, education may also be a means of contributing to conflict transformation, for example, through reforms to the education system itself and by educating people about new arrangements for political representation, justice and policing. Education is the fundamental tool that makes institutional change in other sectors possible by educating personnel currently in post or those who will shape future institutions. Education is also the most powerful tool to develop the economic and social skills necessary to generate sustainable livelihoods for successive generations. The UN Secretary-General suggests that,

"The immediate post-conflict period offers a window of opportunity to provide basic security, deliver peace dividends, shore up and build confidence in the political process, and strengthen core national capacity to lead peacebuilding efforts. If countries succeed in these core areas early on, it substantially increases the chances for sustainable peace - and reduces the risk of relapse into conflict" (2009, p. 1).

Two areas of particular relevance for the role of education in peacebuilding concern research related to 'youth bulges' and the role of education in truth and reconciliation processes. Research by Thyne (2006) found that the higher school enrolment rates (the primary enrolment rate, secondary enrolment rate, and the male secondary enrolment rate), the lower the probability of civil war. The male secondary education enrolment rate was found to have the strongest effect. A more recent study by Barakat \& Urdal (2009) found that a large proportion of young males in the population is likely to increase the risk of conflict in societies where male secondary education enrolment is low. The research suggests the risk is greater when these factors are present in low and middleincome countries. The implications are that education programming in crisis and conflict-affected environments should pay particular attention to male secondary enrolments and youth engagement programs beyond formal education. However, there are also problems with programming that simply characterises young males as a risk to security. Critiques form part of broader concerns about links between aid and security. The GMR (2011) identifies twenty-one developing countries that are spending more on arms and the military than on primary schools and presents evidence that the amount of aid to certain countries may be driven more by global security concerns rather than poverty and need. There is controversy surrounding the use of education as part of counterinsurgency strategy in Iraq and Afghanistan and in programs related to 'youth radicalisation' as part of counter terrorism strategies (Novelli, 2011). The main challenge would therefore seem 
to be the development of education programming that promotes genuine social, economic and political engagement without demonising youth.

In societies that have experienced violent conflict, education also has another important role in longer-term, post-conflict development to help successive generations understand the violent conflict that took place within their own society and potentially contribute towards future peacebuilding. One aspect involves the role of history in teaching about a violent past. Another concerns concepts of truth and reconciliation. These are not necessarily linked, but often are. Cole (2007) indicates how 'the South African Truth and Reconciliation Commission (TRC) was set up as part of the negotiated transition from white majority rule to democratic governance in South Africa as a way to create a public record on the abuses of the apartheid era through public testimony'. She provides an insight into the complexity in working with such concepts, for example, whether 'truth' is objective, subjective or inter-subjective; and whether people are more interested in establishing truth in order to seek justice rather than reconciliation. In addition, even a simple definition of reconciliation as 'a process that brings estranged persons or parties into friendly relations' raises questions about whether it should operate at inter-personal or inter-group level, or even whether groups in conflict have ever had 'friendly relations' at any previous point in their conflict. Despite the dilemmas, Cole suggests that reconciliatory processes must reach beyond maco-level processes involving the legislature, judiciary and military and at some point 'become part of people's lives, and also part of the midlevel and grassroots institutions, such as schools whose workings relate more closely to the lives of average citizens'. She points to the lessons learned from the more positive relations that Germany has built with its neighbours since World War II and the role played by the reform of history education and textbooks.

Further studies have examined the extent to which education has a role in contributing towards reconciliation following recommendations from more recent TRCs. Oglesby (2007) indicates how schools in Guatamala are beginning to incorporate some of the findings from the Guatamalan Historical Clarification Commission. Paulson (2010) highlights how despite commitments to introduce textbooks that dealt with recent conflict in Peru, changes in government can influence whether these are actually used. Buckley-Zistel (2009) examines how the Rwandan government approach was to place a moratorium on the teaching of history after the genocide and the use of ngando camps to promote national unity by promoting a narrative that omits any reference to ethnicity. Paulson (2006) documents how 'the Sierra Leone Truth and Reconciliation Commission (SLTRC) included children's testimony and children guided the development of the children's version of the commission's report'. These research studies also highlight the need for further research into the ethical issues for educators; the role of education in relation to remembrance and commemorative sites and events; and better understanding of the nature of intergenerational learning. It is common, therefore, in countries that have been affected by conflict to point to a role for education in promoting longer-term reconciliation as a means of preventing recurrence of violent conflict. This underlines the fact that peace is often insecure, relapses are frequent and that the main purpose of education interventions at any stage in such cycles is to promote a peacebuilding trajectory.

\section{References}

Amara, M., Azaiza, F., Hertz-Lazarowitz, R., and Mor-Sommerfeld, A.. (2009). A New Bilingual Education in the Conflict-Ridden Israeli Reality. Language and Education, 23 (1), pp.15-35.

Aragon, J. \& Vegas, M. (2009). Governance Evidence in Peru: production and use in the education sector. UNDP: Oslo Governance Centre, Discussion Paper 19.

Barakat, B.F. \& Urdal, H. (2009). Breaking the Waves? Does education mediate the relationship between youth bulges and political violence? Washington DC: World Bank.

Ben-Porath, S.R. (2006). Citizenship under Fire. Democratic Education in Times of Conflict. Princeton, New Jersey: Princeton University Press. 
Bender, P., Dutcher, N., Klaus, D., Shore, J. \& Tesar, C. (2005). In Their Own Language: education for all. Education Notes Series. Washington DC: The World Bank.

Billquist, D.L. \& Colbert, J.M. (2006). Pakistan, Madrassas, and Militancy. Monteray, California: Naval Postgraduate School.

Brock, C. \& McCorriston, M. (2008). Towards the Concept of Education as a Humanitarian Response in the Context of a UNESCO Chair/UNITWIN Context, Paris: UNESCO.

Buckland, P. (2005) Reshaping the future: Education and postconflict reconstruction. Washington, DC: The World Bank.

Buckley-Zistel, S. (2006). Dividing and uniting: the use of citizenship discourses in conflict and reconciliation in Rwanda. Global Society, 20(1), pp.101-113.

Buckley-Zistel, S. (2009). 'Nation, Narration, Unification? The Politics of History Teaching After the Rwandan Genocide'. Journal of Genocide Research, 11(1), pp.31-53.

Bush, K., \& Salterelli, D. (Eds.) (2000). The Two Faces of Education in Ethnic Conflict. Florence: UNICEF Innocenti Research Centre.

Carrión, J. (Ed.) (2006). The Fujimori Legacy: the rise of electoral authoritarianism in Peru. Pennsylvania: Pennsylvania State University Press.

Cole, E.A. (2007). Teaching the Violent Past. History Education and Reconciliation. Plymouth: Rowman and Littlefield Publishers.

Dwyer, A.M. (2005). Policy Studies 15. The Xinjiang Conflict: Uyghur Identity, Language Policy, and Political Discourse. Washington DC: East-West Center.

Gallagher, T. (2010). Key Issues in Coexistence and Education. Coexistence International Brandeis University. Available at http://www.clubmadrid.org/img/secciones/Cl_Key_Issues_in_ Coexistence_Education_Jan_2010.pdf [Retrieved on 18 March 2014].

Global Monitoring Report (2011). The Hidden Crisis: armed conflict and education. Paris: UNESCO.

Grace, G. (2003). Educational Studies and Faith-Based Schooling: moving from prejudice to evidencebased argument. British Journal of Educational Studies. 51(2), pp.149-167.

Grare, F. (2007). The Evolution of Sectarian Conflicts in Pakistan and the Ever-Changing Face of Islamic Violence. South Asia: Journal of South Asian Studies. 30(1), pp.127-143.

Greeley, A. (1998). Catholic schools at the crossroads: an American perspective. In J. M. Feheney (Ed.) From Ideal to Action: The Inner Nature of a Catholic School Today. Dublin: Veritas. pp. 168-178.

Gulalp, Haldun (2006). Citizenship and Ethnic Conflict: challenging the nation-state. Routledge: Research in Comparative Politics.

Hasan, K. (2005). Madrassa enrolment data in Pakistan is 'highly exaggerated'. Available at http:// www.dailytimes.com.pk/default.asp?page=story_2-3-2005_pg7_52. [Retrieved on 14 March 2014]

Höpken, W. (2003). Textbooks and Conflicts. Experiences from the Work of the Georg-Eckert-Institute for International Textbook Research. Washington DC: World Bank Workshop.

Ichilov, Orit (2004). Political Learning and Citizenship Education under Conflict: the political socialization of Israeli and Palestinian youngsters. Abingdon: Routledge

International Crisis Group (2004). Unfulfilled Promises: Pakistan's Failure to Tackle Extremism. Asia Report, No. 73. Available at http://www.crisisgroup.org/en/regions/asia/south-asia/ pakistan/073-unfulfilled-promises-pakistans-failure-to-tackle-extremism.aspx [retrieved 18 March 2014].

INEE. (2010). Minimum Standards for Education: Preparedness, Response, Recovery. New York: InterAgency Network for Education in Emergencies.

Kosonen, K. \& C. Young (2009). Mother Tongue as Bridge Language of Instruction: policies and experiences in Southeast Asia. Bangkok: SEAMEO.

Lawton, D. (2005). Faith schools: Consensus or conflict? London: RoutledgeFalmer.

Lockheed, M. E \& Lewis, M. A., (2007). Inexcusable Absence: why 60 million girls still aren't in school and what to do about it. Washington DC: Center for Global Development. 
Marques, J. \& Bannon, I. (2003). Central America: Education Reform in a Post-Conflict Setting, Opportunities and Challenges. Social Development Department Environmentally and Socially Sustainable Development Network, Working Paper No. 4. Washington, DC: The World Bank.

Novelli, Mario (2011). Are we all soldiers now? The Dangers of the Securitization of Education and Conflict. In Mundy, K. and Dryden-Petersen, S. (eds.) Educating children in conflict zones: research, policy, and practice for systemic change: a tribute to Jackie Kirk. International Perspectives on Education Reform Series. Teachers New York: College Press, pp. 49-66.

Oglesby, E. (2007). Historical Memory and the Limits of Peace Education: examining Guatamala memory of silence and the politics of curriculum design. In E.A. Cole (Ed.) (2007). Teaching the Violent Past. History Education and Reconciliation. Plymouth: Rowman and Littlefield Publishers, pp. 175-204.

O'Malley, B. (2010). Education Under Attack, Paris: UNESCO. Available at http://www.unesco.org. uk/education_under_attack:_unesco_launches_new_report [Retrieved on 10 March 2014]

OSCE (2007). School Catchment Areas in Bosnia and Herzegovina: A Status Report by the OSCE Mission to BiH, Oct 2007. BiH: OSCE

Paulson, J. (2006). The Educational Recommendations of Truth and Reconciliation Commissions: potential and practice in Sierra Leone. Research in Comparative and International Education, 1(4), pp.335-350.

Paulson, J. (2010). Truth Commissions and National Curriculum: The case of the Recordándonos resource in Peru. In S. Parmar, M.J. Roseman, S. Siegrist, \& T. Sowa, (Eds.) Children and Transitional Justice. Truth-Telling, Accountability and Reconciliation. Cambridge, MA: Harvard University Press, pp. 327-364.

Rösel, J. (2009). Mass-education in a Vast, in a Dangerous and a Fragmented State - education policy in India, Pakistan and Sri Lanka. Paper presented at Conference on Education in Fragile Contexts, Arnold- Bergstraesser-Institut, Freiburg, Germany, September 2009.

Shabad, G. and Gunther, R. (1982). Language, Nationalism, and Political Conflict in Spain. Comparative Politics, Vol. 14, No. 4 (Jul., 1982), pp. 443-477.

Short, G. (2002). Faith-Based Schools: a threat to social cohesion? Journal of Philosophy of Education. 36(4), pp. 559-572.

Smith, A. (2003) Citizenship Education in Northern Ireland: beyond national identity? Cambridge Journal of Education, 33(1), pp. 15-31.

Smith, A. \& Vaux, T. (2003). Education, Conflict, and International Development. London: Department of International Development.

Spink, J. (2005). Education and politics in Afghanistan: the importance of an education system in peacebuilding and reconstruction. Journal of Peace Education, 2(2), pp.195-207.

Stewart, F. (2000). Crisis Prevention: tackling horizontal inequalities. Oxford Development Studies, 28 (3), pp. 245-262

Tawil, S. \& Harley, A. (Eds.) (2004). Education, Conflict and Social Cohesion. Geneva: UNESCO IBE.

Thyne, C.L. (2006). ABC's, 123's, and the Golden Rule: the pacifying effect of education on civil war, 1980-1999. International Studies Quarterly, 50, pp.733-754.

UNESCO (2003). Education in a Multilingual World. UNESCO Education Position Paper. Paris: UNESCO. UNICEF (2008). Divided Schools in Bosnia and Herzegovina. Sarajevo: UNICEF.

United Nations (1948). The Universal Declaration of Human Rights. New York: United Nations General Assembly.

United Nations (1989). Convention on the Rights of the Child. New York: United Nations, Office of the United Nations High Commissioner for Human Rights.

United Nations Commission on Human Rights Report (1995) Implementation of the declaration on the eliminations of all forms of intolerance and of discrimination based on religion or belief, article 66 (E/CN.4/1996/95) 
United Nations (2007). Report of Special Rapporteur on the Right to Education: Mission to Bosnia and Herzegovina (24 September- 2 October 2007). Available at: http://www.refworld.org/ docid/484d1c142.html [Retrieved on 11 February 2014]

United Nations (2009). Report of the Secretary-General on Peacebuilding in the Immediate Aftermath of Conflict. New York: United Nations General Assembly and Security Council.

United Nations (2010). Children and Armed Conflict: Report of the Secretary-General. New York: United Nations General Assembly and Security Council.

Wickrema. A. \& Colenso, P. (2003). Respect for Diversity in Educational Publication. The Sri Lankan Experience. Washington DC: World Bank Workshop.

World Bank (2005). 'In Their Own Language...Education for All'. Education Notes 38906. Washington, DC: The World Bank. 